\title{
Carrier Flotation of Low-Rank Coal with Polystyrene
}

\author{
Gen Huang *, Jiaqi Xu, Pengyue Geng and Jihui Li *(1) \\ School of Chemical \& Environmental Engineering, China University of Mining and Technology-Beijing, \\ Beijing 100083, China; 18811770575@163.com (J.X.); gpy15738512027@126.com (P.G.) \\ * Correspondence: huanggen@cumtb.edu.cn (G.H.); lijihui@cumtb.edu.cn (J.L.)
}

Received: 1 April 2020; Accepted: 16 May 2020; Published: 18 May 2020

\begin{abstract}
The problem of low-rank coal flotation continues to be a challenge due to the poor hydrophobicity and abundant oxygenated functional groups on particle surfaces. In this study, carrier flotation was used to improve the flotation performance of low-rank coal with polystyrene as a carrier material. Kerosene was used as a collector and played a role in the adhesion of fine low-rank coal to polystyrene due to its hydrophobic properties. The carrier feature of polystyrene was demonstrated by Turbiscan Lab Expert stability analysis and scanning electron microscopy analysis. The flotation experiments revealed that the optimum conditions were: collector dosage $5000 \mathrm{~g} / \mathrm{t}$, pulp concentration $40 \mathrm{~g} / \mathrm{L}$, and the ratio of low-rank coal to polystyrene 100:10. Under these conditions, the combustible recovery by carrier flotation was obtained as $70.59 \%$ when the ash content was $12.32 \%$, which increased by 25.68 points compared with the combustible recovery of conventional flotation under almost the same ash content. The fine coal particles coated the coarse polystyrene particles through hydrophobic interactions between the polystyrene and hydrocarbon chains of the kerosene adsorbed on coal particles. The results suggested that the flotation performance of low-rank coal was significantly improved by carrier flotation with polystyrene, especially for fine particles.
\end{abstract}

Keywords: carrier flotation; polystyrene; low-rank coal; combustible recovery

\section{Introduction}

Froth flotation is an efficient method for the upgrading of fine coals of less than $0.5 \mathrm{~mm}$ [1-3]. However, low-rank coals are very difficult to float with ordinary collectors (diesel oil, kerosene, etc.) due to abundant oxygenated functional groups on their surfaces, such as hydroxyl and carboxyl groups, which hinder the adsorption between low-rank coal particles and collectors [4,5]. Numerous researchers have contributed to exploit new collectors [6-10] and particle surface treatments (ultrasonic, grinding, heat treatment and microwave, etc.) [11-14] for improving the flotation performance of low-rank coals. However, the problem of low efficiency in low-rank coal flotation has not been resolved.

Carrier flotation has been tested in a variety of ores, and proven to be beneficial for improving flotation performances [15-18]. In this technique, the particles which will be floated coat the carrier materials, and all of them are floated together [19]. The increase of particle size by carrier flotation will improve the contact frequency and attachment probability between fine particles and air bubbles. Polystyrene is an aromatic polymer synthesized from styrene monomers of $\left(\mathrm{C}_{8} \mathrm{H}_{8}\right)_{\mathrm{n}}$. Polystyrene is hydrophobic because of the long hydrocarbon chains at the carbon center of the phenyl group [20,21], and polystyrene particles have a large specific surface area due to long-term weathering [22,23]. Therefore, the polystyrene was usually used for carrier flotation. Zhang et al. [24] showed a maximum recovery of $95.69 \%$ in scheelite carrier flotation by using polystyrene particle as the carrier materials. However, the carrier flotation of polystyrene in low-rank coal was seldom studied.

In this study, the carrier flotation was used to improve flotation performance of low-rank coal with polystyrene as the carrier material. The flotation performances between conventional flotation and 
carrier flotation were compared when kerosene was used as a collector. Turbiscan Lab Expert stability and scanning electron microscopy (SEM) analyses were applied to analyze particle aggregation.

\section{Experimental}

\subsection{Materials}

The representative long flame coal pulp sample was collected from Shanxi province, China, and the $+0.2 \mathrm{~mm}$ particles were removed from the pulp by the wet screening. After being filtered and dried at $60{ }^{\circ} \mathrm{C}$, the coal sample of $-0.2 \mathrm{~mm}$ particles was stored in a container and sealed for further analysis and experiments. The size distribution of the coal sample was analyzed by sieving analysis, and the mineral composition of the coal sample was identified by XRD (Brook D8 Advance, Bruker, Karlsruhe, German). Polystyrene particles $(0.3-0.5 \mathrm{~mm})$ with a purity of $91 \%-94 \%$ were provided by Taita Chemical Co., Ltd., Suzhou, China. Kerosene (purity $\geq 99 \%$ ) was used as collector and octanol (purity $\geq 99 \%$ ) was used as frother.

The coal sample was screened to $0.20-0.125,0.125-0.074,0.074-0.045$, and $-0.045 \mathrm{~mm}$ fractions. The results are presented in Table 1, which shows that the yield of $-0.045 \mathrm{~mm}$ fine particles reached almost $50 \%$ with the highest ash content of $37.57 \%$. The high content of fine particles made conventional flotation difficult.

Table 1. Size distribution of the coal sample.

\begin{tabular}{ccccc}
\hline Size Fraction $(\mathbf{m m})$ & Yield (\%) & Ash (\%) & Cumulative Yield on Screen (\%) & Cumulative Ash (\%) \\
\hline $0.2-0.125$ & 10.58 & 11.28 & 10.58 & 11.28 \\
$0.125-0.074$ & 25.10 & 14.52 & 35.68 & 13.56 \\
$0.074-0.045$ & 14.67 & 22.99 & 50.35 & 16.31 \\
-0.045 & 49.65 & 37.57 & 100.00 & 26.87 \\
Total & 100.00 & $26.87 \%$ & & \\
\hline
\end{tabular}

Figure $1 \mathrm{a}, \mathrm{b}$ show the XRD spectrums of the polystyrene particles and the coal sample. Only one broad diffuse peak appeared at $2 \theta=20^{\circ}$ in the XRD spectrum of polystyrene (Figure 1a), indicating the high purity of the polystyrene sample. However, the low-rank coal of $-0.2 \mathrm{~mm}$ included some impurities such as kaolinite, montmorillonite, quartz, and calcite. As known form literature, kaolinite and montmorillonite minerals could cause slime coating and hence affect flotation performance $[25,26]$.
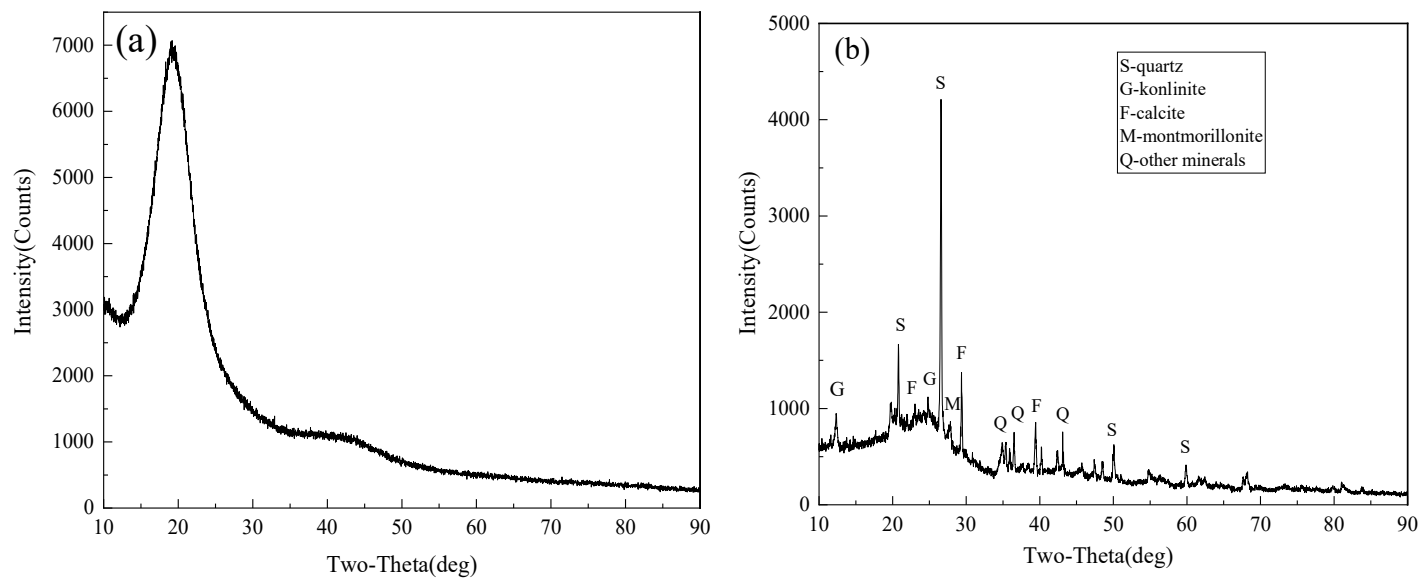

Figure 1. XRD results of: (a) polystyrene and (b) coal samples.

\subsection{Contact Angle Measurements}

The contact angle is used to describe the wettability of solid-liquid surface and was measure by sessile drop method [27]. Polystyrene particles were prepared into gelatin films for contact angle 
measurements [28,29]. Polystyrene $(20 \mathrm{~g})$ was dissolved in toluene $(100 \mathrm{~mL})$ at $25{ }^{\circ} \mathrm{C}$ for $180 \mathrm{~min}$. The solution was painted into clean glass slides evenly and dried $24 \mathrm{~h}$ at $25^{\circ} \mathrm{C}$ [30]. The low-rank coal powder of $-0.045 \mathrm{~mm}(0.4 \mathrm{~g})$ was pressed into round piece, and the contact angle values of polystyrene film and coal were measured by a HARKE-SPACE Contact Angle equipment (Ha Ke Test Instrument Factory, Beijing, China). The measurement range of contact Angle was from 0 to $180^{\circ}$, and the measurement accuracy was $\pm 0.1^{\circ}$. The contact angles were measured three times and averaged value was presented. The contact angle of the polystyrene film was determined as $83.4^{\circ}$, and the contact angle of low-rank coal $(-0.045 \mathrm{~mm})$ was $37.2^{\circ}$.

\subsection{Flotation Experiments}

Flotation experiments were carried out in a $500 \mathrm{~mL}$ flotation cell at an impeller speed of $2100 \mathrm{rpm}$. In each test, the predetermined amounts of polystyrene, coal, and deionized water (electrical conductivity $<5 \mu \mathrm{s} / \mathrm{cm}$ ) obtained from an ultrapure water machine (UPW-R30, Inesa Scientific Instrument Co., Ltd., Shanghai, China) were added to the flotation cell to form a $500 \mathrm{~mL}$ uniform pulp which was agitated for $1 \mathrm{~min}$, then kerosene was added to the flotation cell by a microinjector, and the pulp was agitated for $2 \mathrm{~min}$. Octanol $(600 \mathrm{~g} / \mathrm{t})$ was finally added, and an additional $1 \mathrm{~min}$ agitation was proceeded. After the above-mentioned steps, the flotation cell was aerated, and the airflow rate was controlled by a flowmeter. The particles were floated for 5 min with an airflow rate of $0.63 \mathrm{~cm} / \mathrm{s}$. After the flotation process, the polystyrene particles in float and sink products were separated from coal particles by $0.25 \mathrm{~mm}$ sieving, and the combustible recovery and ash content were calculated after removing polystyrene particles. The flotation experiments were conducted three times, and the average value and standard deviations were reported. The flotation performance was evaluated by combustible recovery of concentrate and flotation efficiency using the following equation. The combustible recovery $\varepsilon$ and flotation efficiency $\eta$ are defined as [31]:

$$
\begin{gathered}
\varepsilon=\frac{M_{C}\left(100-A_{C}\right)}{M_{F}\left(100-A_{F}\right)} \\
\eta=\frac{M_{C} \times\left(A_{F}-A_{C}\right)}{M_{F} \times A_{F} \times\left(100-A_{F}\right)} \times 100 \%
\end{gathered}
$$

where, $\varepsilon$ - the combustible recovery of concentrate, $\% ; \eta$-the flotation efficiency index, $\% ; M_{C}$-the mass of concentrate, $\mathrm{kg} ; M_{F}$-the mass of feed, $\mathrm{kg} ; A_{C}$-the ash content of concentrate, \%; and $A_{F}$-the ash content of feed, \%.

\subsection{Aggregation Analysis}

The particle aggregation performances in the pulp before the flotation was investigated using a Turbiscan Lab Expert (Formulaction, Toulouse, France), which could measure the stability of opaque and concentrated suspensions without affecting it. The Turbiscan includes a transmission light detector and a backfired light detector [32]. The transmitted light detector receives the transmitted light passing through the sample, while the backfired light detector receives the reflected backscattered light [33]. This measurement is based on a change in droplet volume fraction (migration) or average size (merge), which results in a change in backscattering (BS) and transmission ( $T$ ) signals [34]. By using the BS and $T$ profiles, the pulp destabilization can be analyzed [35]. The relationship between $B S$ value and photon transmission mean free path $l^{*}$, volume fraction of particles $\emptyset$, and mean particle diameter $\mathrm{d}$ is shown in Equation (3) [32]:

$$
B S=\frac{1}{\sqrt{l^{*}}}=\sqrt{\frac{3 \varnothing(1-g) Q_{s}}{2 d}}
$$

where, $g$ is the asymmetric factor, $Q_{S}$ is the extinction section divided by the geometrical cross-section, which was given by the Mie theory. It can be seen from the Equation (1), the $B S$ value is inversely proportional to the square root of particle mean diameter $d$. 
The turbiscan stability index (TSI) value could evaluate the stability of a sample by measuring light intensity variations [36]. The TSI can be expressed by:

$$
\mathrm{TSI}=\sum_{i=1}^{n} \frac{\sum h\left|\operatorname{scan}_{i}(h)-\operatorname{scan}_{i-1}(h)\right|}{H}
$$

where, $H$ is the total height of the sample, $h$ is the scanning point height, $\operatorname{scan}_{i}(h)$ and $\operatorname{scan}_{i-1}(h)$ are the light intensity values measured at $i$ and $i-1$ times, respectively.

After kerosene was added into the pulp and agitated for $2 \mathrm{~min}$ as shown in Section 2.3, an $8 \mathrm{~mL}$ sample was pipetted from the pulp $(500 \mathrm{~mL})$. Then, the sample was transferred to a transparent glass bottle (height $55 \mathrm{~mm}$, volume $30 \mathrm{~mL}$ ) for aggregation analyses.

\subsection{SEM Analysis}

The aggregates in the carrier flotation were observed by using a JEM-7800F scanning electron microscope (SEM, Jeol, Tokyo, Japan). The samples were prepared by dropping suspensions on a sample carrier, followed by drying naturally and then gold coating. The detailed operating parameters were: accelerating voltage $15.00 \mathrm{kV}$, working distance $10.20 \mathrm{~mm}$ and pressure $-5 \times 10^{-4} \mathrm{~Pa}$.

\section{Results and Discussion}

\subsection{Carrier Flotation Experiments}

\subsubsection{Effect of Kerosene Dosage on Flotation Performance}

Kerosene dosage has an important influence on coal flotation, especially for low-rank coal. Figure 2 shows the flotation indices as a function of kerosene dosage with polystyrene as the carrier material under the following flotation conditions: pulp concentration $40 \mathrm{~g} / \mathrm{L}$ and the mass ratio of coal to polystyrene 100:10. As seen from Figure 2, the flotation recovery increased from $37.93 \%$ to $69.60 \%$ when kerosene dosage increased from 1000 to $5000 \mathrm{~g} / \mathrm{t}$. Additionally, the ash of clean coal decreased from $17.10 \%$ to $12.25 \%$. A further increase in kerosene dosage up to $6000 \mathrm{~g} / \mathrm{t}$ resulted in a notable increase in ash content, but a minor increase in recovery. The flotation efficiency shows the same trend as the flotation recovery, and the maximum $\eta$ value (51.95\%) was obtained at $5000 \mathrm{~g} / \mathrm{t}$ kerosene. This optimum kerosene dosage was used at the following flotation experiments.

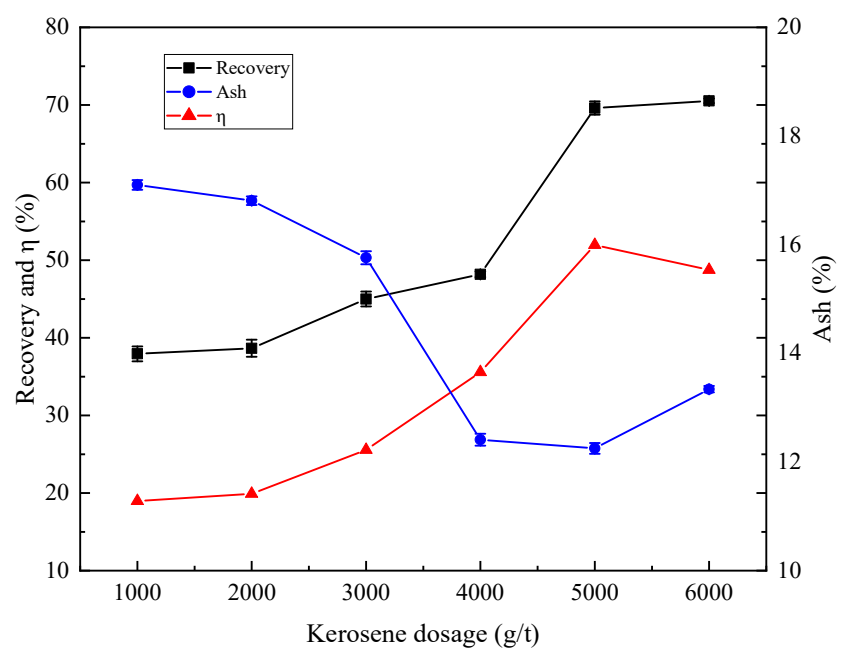

Figure 2. Effect of kerosene dosage on flotation indices. 


\subsubsection{Effect of Pulp Concentration on Flotation Performance}

Figure 3 shows the effect of pulp concentration on flotation indices when the kerosene dosage was fixed at $5000 \mathrm{~g} / \mathrm{t}$ and the mass ratio of coal to polystyrene was 100:10. Both the recovery and ash of clean coal increased with the increase of pulp concentration, and the maximum $\eta$ value (52.72\%) was obtained when the pulp concentration was $40 \mathrm{~g} / \mathrm{L}$. Although the increasing pulp concentration is beneficial to improve the flotation recovery, the ash content in the concentrate also significantly increased. There, the optimum pulp concentration was chosen as $40 \mathrm{~g} / \mathrm{L}$.

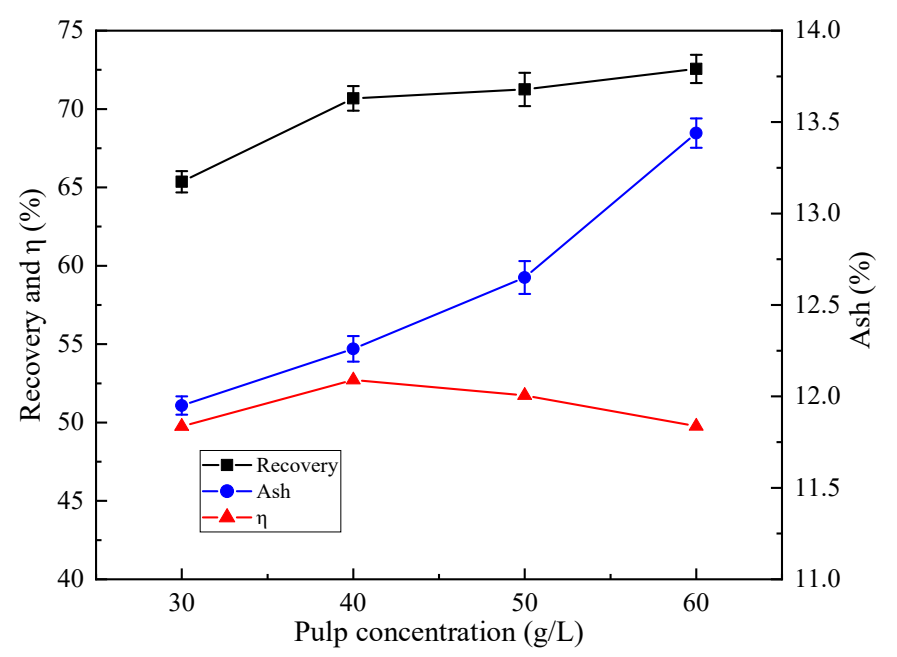

Figure 3. Effect of pulp concentration on flotation indices.

\subsubsection{Effect of the Mass Ratio of Coal to Polystyrene on Flotation Performance}

Figure 4 shows the effect of the mass ratio of coal to polystyrene on flotation indices at $5000 \mathrm{~g} / \mathrm{t}$ collector dosage and $40 \mathrm{~g} / \mathrm{L}$ pulp concentration. The flotation efficiency index increased with the increase of polystyrene ratio, reaching the maximum value (52.43\%) at the ratio of 100:10. A further increase of polystyrene resulted in a decreased flotation efficiency, which may be due to the increased adsorption of high-ash coal by excessive polystyrene particles. The concentrate recovery by conventional flotation were only $44.19 \%$ with an ash content of $12.72 \%$ when the carrier materials were not added. And, the flotation efficiency index was 31.93\%. Compared to the results at the ratio of 100:10, the recovery increased $26.40 \%$, the ash decreased $0.40 \%$, and the flotation efficiency index increased $20.50 \%$. The addition of carrier can promote fine coal flotation.

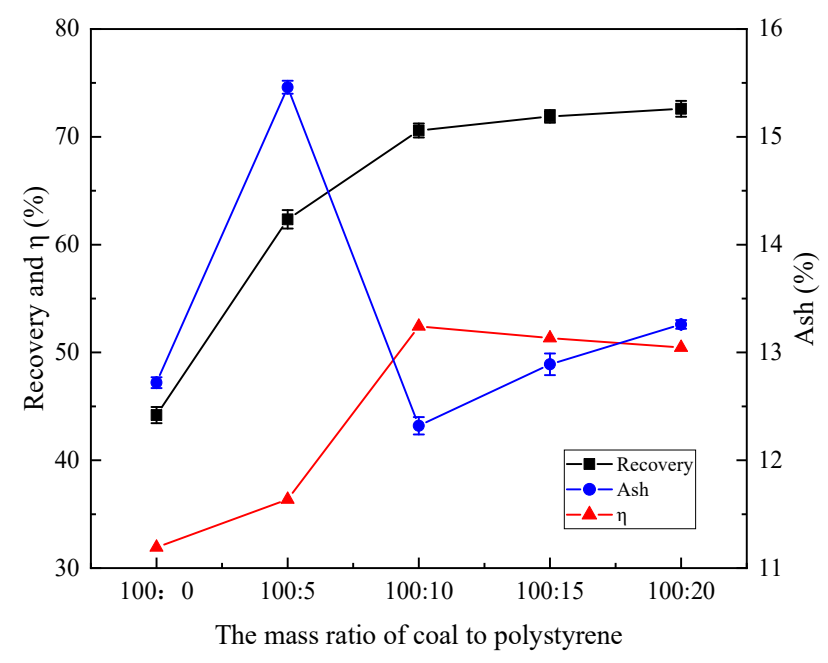

Figure 4. Effect of mass ratio of coal to polystyrene on flotation indices. 


\subsubsection{Carrier Flotation Performance of Coal in Difference Size Fractions}

To further confirm the flotation performance of coal in different size fractions with and without polystyrene particles as carrier materials, the $-0.2 \mathrm{~mm}$ coal sample was sieved into four size fractions $(0.2-0.125 \mathrm{~mm}, 0.125-0.074 \mathrm{~mm}, 0.074-0.045 \mathrm{~mm}$, and $-0.045 \mathrm{~mm})$. Figure 5 shows the flotation recovery and ash content of clean coal in different size fractions by the carrier flotation and conventional flotation (no polystyrene particles added). Compared with conventional flotation, the combustible recovery of clean coal for all the four size fractions were increased when polystyrene was added as carrier materials. Especially for the $-0.045 \mathrm{~mm}$ fraction, the recovery of carrier flotation increased by 11.55 points compared with that of conventional flotation without polystyrene particles, which was due to the adhesion between coarse carrier particles and fine coal [19].

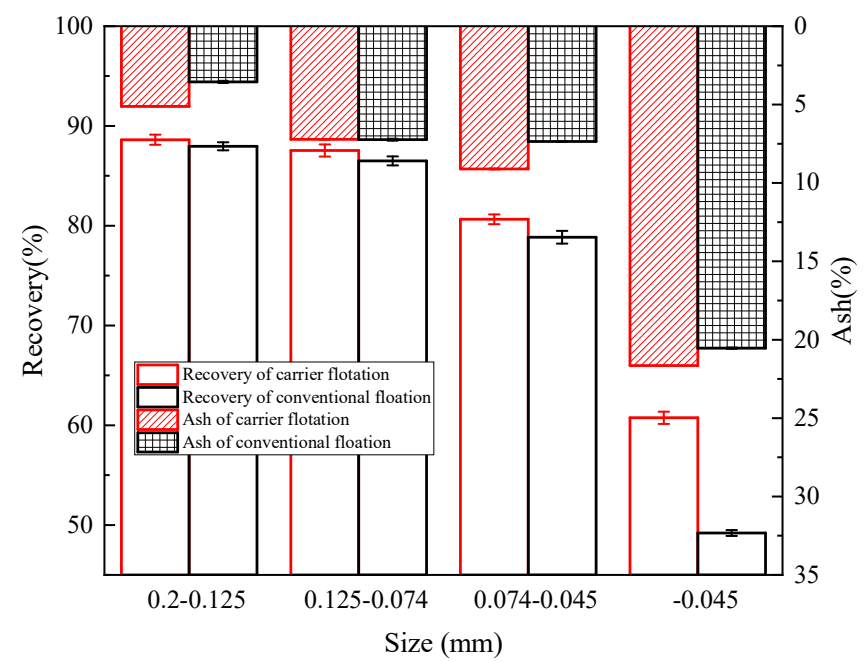

Figure 5. Flotation performance of coal in different size fractions with and without adding polystyrene particles.

The polystyrene particles in clean coal and tailings were separated from coal particles by sieving with a $0.25 \mathrm{~mm}$ screen, and the flotation recovery of polystyrene particles was calculated (Table 2). The recovery of polystyrene particles added to different coal fractions were over $98 \%$, indicating that almost all the polystyrene particles were floated with clean coal and recovery by flotation.

Table 2. Recovery of polystyrene particles after carrier flotation with different coal fractions.

\begin{tabular}{cc}
\hline Size Fraction of Coal $\mathbf{( m m})$ & Recovery of Polystyrene Particles $\mathbf{( \% )}$ \\
\hline $0.2-0.125$ & 98.58 \\
$0.125-0.074$ & 99.10 \\
$0.074-0.045$ & 98.67 \\
-0.045 & 98.65 \\
\hline
\end{tabular}

\subsection{The Variation of BS Value with and without Polystyrene Particles}

Figure 6 shows the $\triangle B S$ profiles of the coal slurry as a function of settling time with and without polystyrene particles. The sample bottle could be divided into three areas: the top $35-40 \mathrm{~mm}$, the middle $35-5 \mathrm{~mm}$, and the bottom $5-0 \mathrm{~mm}$. The migration of particles from the top to the bottom of the sample leads to a decrease in the concentration at the top of the sample, resulting in an increase in the variation of $B S$ (positive peak) [32] at the top area of the sample. When polystyrene was added to the sample, the $\triangle B S$ values had a further increase, which may be due to the particle aggregation between polystyrene and fine coal particles. Figure 7 shows the TSI variation of the coal slurry as a function of setting time with and without polystyrene particles. The TSI value was calculated by the turbiscan software (Formulaction, Toulouse, France), and higher TSI value indicates the more unstable of the 
system. It can be seen from Figure 7 that the TSI value was increased when polystyrene was added, indicating the coal system became more unstable when polystyrene was added.
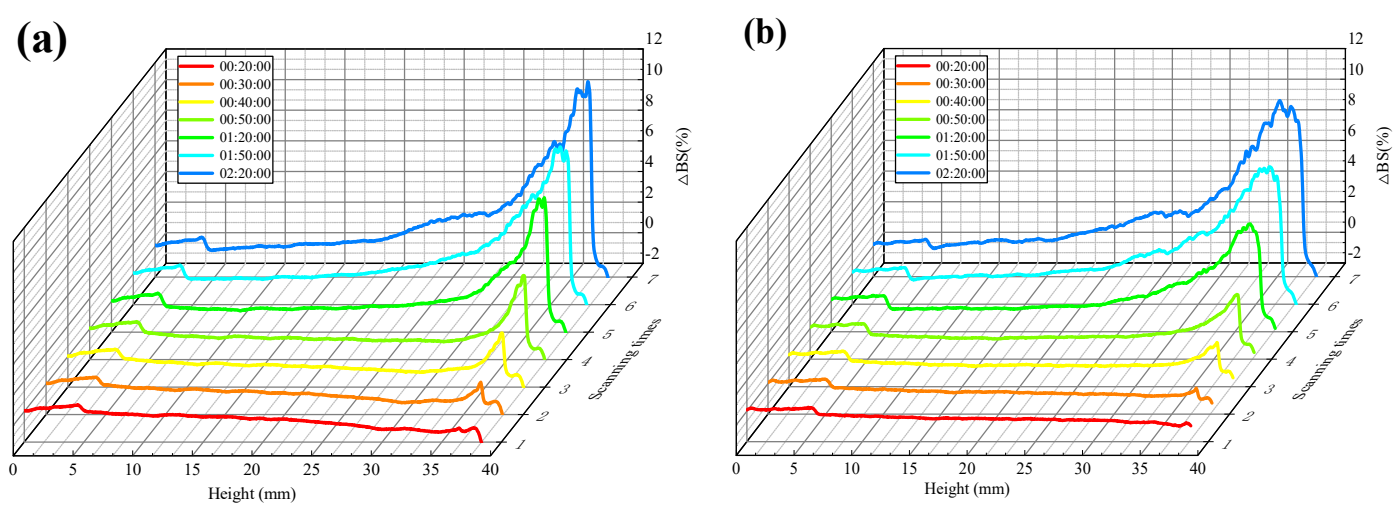

Figure 6. $\triangle B S$ (backscattering) profiles of the coal slurry as a function of settling time with and without polystyrene particles. (a) with polystyrene particles; (b) without polystyrene particles.

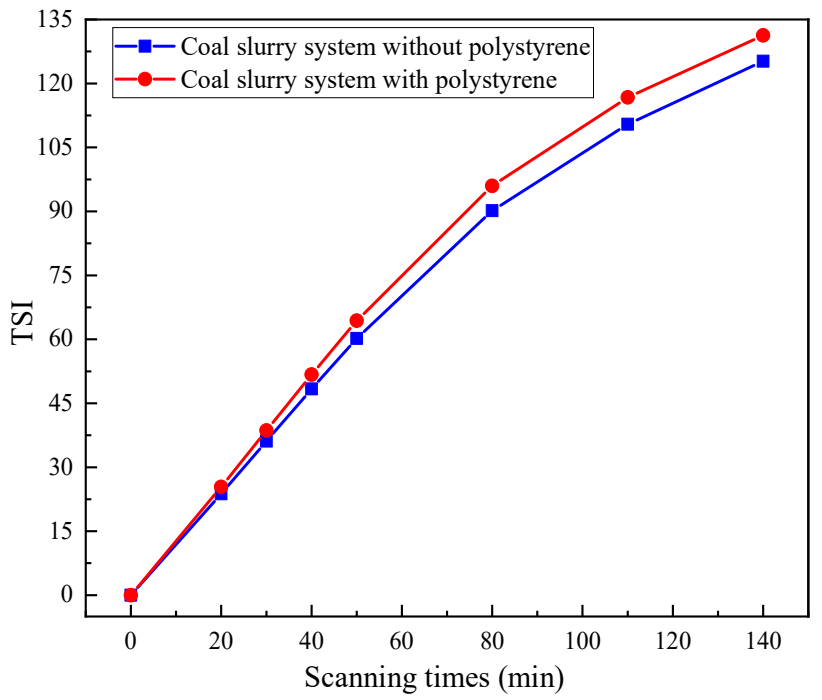

Figure 7. TSI variation of the coal slurry as a function of settling time with and without polystyrene particles.

\subsection{SEM Analysis}

The SEM analyses with and without polystyrene were performed, and the results are shown in Figure 8. When polystyrene particles were added, many fine coal particles covered on the surfaces of coarse polystyrene particles as seen in Figure $8 \mathrm{c}, \mathrm{d}$, which exactly suggested that the carrier flotation occurred. This covering of coal on coarse polystyrene particles increased the coal particle size during flotation thereby made coal particles easier to attach themselves to bubbles. As expected, the flotation recovery of coal significantly increased with the increasing size of aggregates. However, it should be noted that most of the coal particles covered on the edges of the polystyrene particles. 

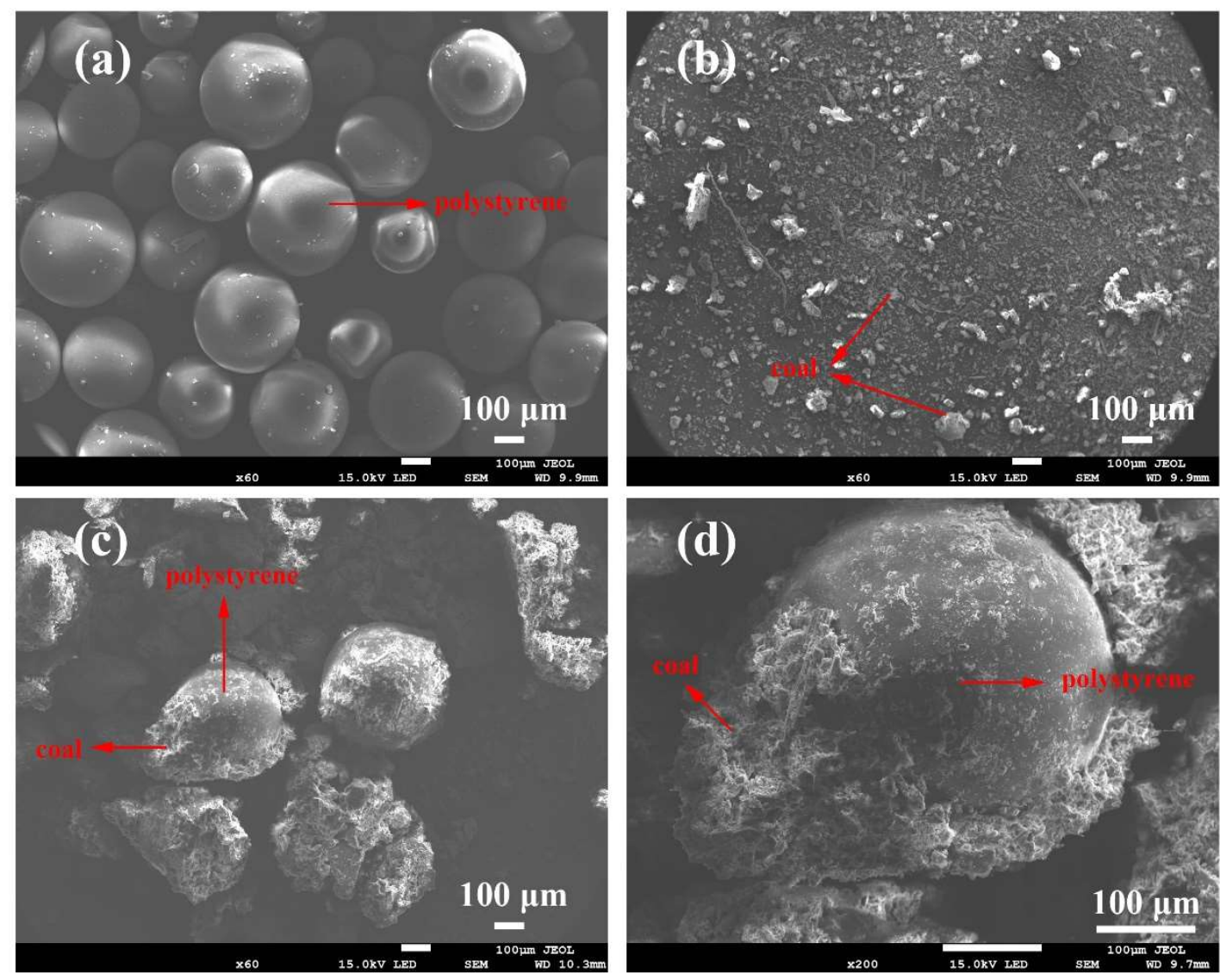

Figure 8. Scanning electron microscopy (SEM) photographs: (a) polystyrene, (b) coal after conditioning, and $(\mathbf{c}, \mathbf{d})$ coal and polystyrene after conditioning.

\section{Conclusions}

(1) The flotation of fine coal particles was enhanced by adding coarse polystyrene particles as carriers. Under the optimized flotation conditions, the combustible recovery was $70.59 \%$ when the ash content was $12.72 \%$ by the carrier flotation, while the conventional flotation recovery without polystyrene was only $44.19 \%$. The flotation recovery increased by 26.40 points at almost the same ash content.

(2) The $\triangle B S$ and TSI were increased and the coal slurry system became more unstable when polystyrene particles were added, indicating that the particle aggregation between polystyrene and fine coal particles occurred.

(3) Fine coal particles could cover on the polystyrene particles and this covering increased the coal particle size during flotation. The newly enlarged particle aggregates would enhance the collision probability between the particle and bubble, and hence improve flotation performances.

(4) The results suggested that the flotation performance of low-rank coal was significantly improved by carrier flotation with polystyrene, especially for fine particles. It appears to be a promising method for low-rank coal flotation. However, more fundamental investigations are required for industrial application.

Author Contributions: Data curation, J.X.; Methodology, G.H. and J.L.; Project administration, G.H. and J.L.; Supervision, P.G.; Writing_original draft, J.X.; Writing—review \& editing, G.H. All authors have read and agreed to the published version of the manuscript.

Funding: This work was supported by the National Natural Science Foundation of China (Grant no.51504262, 51604280) and the China Scholarship Council.

Conflicts of Interest: The authors declare no conflict of interest. 


\section{References}

1. Cebeci, Y. The investigation of the floatability improvement of Yozgat AyrÄądam lignite using various collectors. Fuel 2002, 81, 281-289. [CrossRef]

2. Jia, R.; Harris, G.H.; Fuerstenau, D.W. An improved class of universal collectors for the flotation of oxidized and/or low-rank coal. Int. J. Miner. Process. 2000, 58, 99-118. [CrossRef]

3. Dey, S. Enhancement in hydrophobicity of low rank coal by surfactants-A critical overview. Fuel Process. Technol. 2012, 94, 151-158. [CrossRef]

4. Harris, G.H.; Diao, J.; Fuerstenau, D.W. Coal Flotation with Nonionic Surfactants. Coal Prep. 1995, 16, $135-147$. [CrossRef]

5. Polat, M.; Polat, H.; Chander, S. Physical and chemical interactions in coal flotation. Int. J. Miner. Process. 2003, 72, 199-213. [CrossRef]

6. Chander, S.; Polat, H.; Mohal, B. Flotation and wettability of a low-rank coal in the presence of surfactants. Miner. Metall. Process. 1994, 11, 55-61. [CrossRef]

7. Gui, X.; Xing, Y.; Wang, T.; Cao, Y.; Miao, Z.; Xu, M. Intensification mechanism of oxidized coal flotation by using oxygen-containing collector Îa-furanacrylic acid. Powder Technol. 2017, 305, 109-116. [CrossRef]

8. Medyanik, N.L.; Shadrunova, I.V.; Girevaya, K.Y.; Kalugina, N.L.; Varlamova, I.A.; Bod'yan, L.A. Flotation activity of esters in coal beneficiation processes. Solid Fuel Chem. 2015, 49, 319-323. [CrossRef]

9. Tian, Q.; Zhang, Y.; Li, G.; Wang, Y. Application of Carboxylic Acid in Low-Rank Coal Flotation. Int. J. Coal Prep. Util. 2017, 39, 44-53. [CrossRef]

10. Xing, Y.; Li, C.; Gui, X.; Cao, Y. Interaction Forces between Paraffin/Stearic Acid and Fresh/Oxidized Coal Particles Measured by Atomic Force Microscopy. Energy Fuels 2017, 31, 3305-3312. [CrossRef]

11. Xia, W.; Yang, J.; Liang, C. Effect of microwave pretreatment on oxidized coal flotation. Powder Technol. 2013, 233, 186-189. [CrossRef]

12. Xu, M.; Xing, Y.; Gui, X.; Cao, Y.; Wang, D.; Wang, L. Effect of Ultrasonic Pretreatment on Oxidized Coal Flotation. Energy Fuels 2017, 31, 14367-14373. [CrossRef]

13. Ateşok, G.; Çelik, M.S. A new flotation scheme for a difficult-to-float coal using pitch additive in dry grinding. Fuel 2000, 79, 1509-1513. [CrossRef]

14. Ozdemir, O.; Ersoy, O.F.; Guven, O.; Turgut, H.; Cinar, M.; Çelik, M.S. Improved flotation of heat treated lignite with saline solutions containing mono and multivalent ions. Physicochem. Probl. Miner. Process. 2018, 54, 1070-1082. [CrossRef]

15. Fuerstenau, D.W.; Li, C.; Hanson, J.S. Shear flocculation and carrier flotation of fine hematite. In Production and Processing of Fine Particles; Plumpton, A.J., Ed.; Pergamon: Amsterdam, The Netherlands, 1988; pp. 329-335. [CrossRef]

16. Hu, N.; Liu, W.; Jin, L.; Li, Y.; Li, Z.; Liu, G.; Huang, D.; Wu, Z.; Yin, H. Recovery of trace Cu 2+ using a process of nano-adsorption coupled with flotation: SNP as an adsorbing carrier. Sep. Purif. Technol. 2017, 184, 257-263. [CrossRef]

17. Subrahmanyam, T.V.; Forssberg, K.S.E. Fine particles processing: Shear-flocculation and carrier flotation-A review. Int. J. Miner. Process. 1990, 30, 265-286. [CrossRef]

18. Eckert, K.; Schach, E.; Gerbeth, G.; Rudolph, M. Carrier Flotation: State of the Art and its Potential for the Separation of Fine and Ultrafine Mineral Particles. Mater. Sci. Forum 2019, 959, 125-133. [CrossRef]

19. Ateşok, G.; Boylu, F.; Çelǐk, M.S. Carrier flotation for desulfurization and deashing of difficult-to-float coals. Miner. Eng. 2001, 14, 661-670. [CrossRef]

20. Basarova, P.; Bartovska, L.; Korinek, K.; Horn, D. The influence of flotation agent concentration on the wettability and flotability of polystyrene. J. Colloid Interface Sci. 2005, 286, 333-338. [CrossRef]

21. Yang, S.T.; Pelton, R.; Raegen, A.; Montgomery, M.; Dalnoki-Veress, K. Nanoparticle Flotation Collectors: Mechanisms Behind a New Technology. Langmuir 2011, 27, 10438-10446. [CrossRef]

22. Brennecke, D.; Duarte, B.; Paiva, F.; Cacador, I.; Canning-Clode, J. Microplastics as vector for heavy metal contamination from the marine environment. Estuar. Coast. Shelf Sci. 2016, 178, 189-195. [CrossRef]

23. Dong, Y.M.; Gao, M.L.; Song, Z.G.; Qiu, W.W. As(III) adsorption onto different-sized polystyrene microplastic particles and its mechanism. Chemosphere 2020, 239, 11. [CrossRef] [PubMed]

24. Zhang, X.F.; Hu, Y.H.; Sun, W.; Xu, L.H. The Effect of Polystyrene on the Carrier Flotation of Fine Smithsonite. Minerals 2017, 7, 52. [CrossRef] 
25. Xu, Z.H.; Liu, J.J.; Choung, J.W.; Zhou, Z.A. Electrokinetic study of clay interactions with coal in flotation. Int. J. Miner. Process. 2003, 68, 183-196. [CrossRef]

26. Yu, Y.; Li, A.; Xu, Z.; Zhou, A.; Li, Z.; Zhang, N.; Qu, J.; Zhu, X.; Liu, Q. New insights into the slime coating caused by montmorillonite in the flotation of coal. J. Clean. Prod. 2020, 242, 118540. [CrossRef]

27. Alghunaim, A.; Kirdponpattara, S.; Newby, B.-M.Z. Techniques for determining contact angle and wettability of powders. Powder Technol. 2016, 287, 201-215. [CrossRef]

28. Guney, A.; Ozdilek, C.; Kangal, M.O.; Burat, F. Flotation characterization of PET and PVC in the presence of different plasticizers. Sep. Purif. Technol. 2015, 151, 47-56. [CrossRef]

29. Białopiotrowicz, T.; Jańczuk, B. The changes of the surface free energy of the adsorptive gelatin films. Eur. Polym. J. 2001, 37, 1047-1051. [CrossRef]

30. Yousif, E.; Ahmed, D.S.; El-Hiti, G.A.; Alotaibi, M.H.; Hashim, H.; Hameed, A.S.; Ahmed, A. Fabrication of Novel Ball-Like Polystyrene Films Containing Schiff Base Microspheres as Photostabilizers. Polymers 2018, 10, 1185. [CrossRef]

31. Xia, W.C.; Yang, J.G.; Liang, C. Improving Oxidized Coal Flotation Using Biodiesel as a Collector. Int. J. Coal Prep. Util. 2013, 33, 181-187. [CrossRef]

32. Celia, C.; Trapasso, E.; Cosco, D.; Paolino, D.; Fresta, M. Turbiscan Lab ${ }^{\circledR}$ Expert analysis of the stability of ethosomes ${ }^{\circledR}$ and ultradeformable liposomes containing a bilayer fluidizing agent. Colloids Surf. B Biointerfaces 2009, 72, 155-160. [CrossRef]

33. Qin, Y.L.; Yu, L.X.; Wu, R.C.; Yang, D.J.; Qiu, X.Q.; Zhu, J.Y. Biorefinery Lignosulfonates from Sulfite-Pretreated Softwoods as Dispersant for Graphite. ACS Sustain. Chem. Eng. 2016, 4, 2200-2205. [CrossRef]

34. Lemarchand, C.; Couvreur, P.; Vauthier, C.; Costantini, D.; Gref, R. Study of emulsion stabilization by graft copolymers using the optical analyzer Turbiscan. Int. J. Pharm. 2003, 254, 77-82. [CrossRef]

35. Liu, J.; Huang, X.; Lu, L.; Li, M.; Xu, J.; Deng, H. Turbiscan Lab ${ }^{\circledR}$ Expert analysis of the biological demulsification of a water-in-oil emulsion by two biodemulsifiers. J. Hazard. Mater. 2011, 190, $214-221$. [CrossRef] [PubMed]

36. Ren, Y.; Zheng, J.; Xu, Z.; Zhang, Y.; Zheng, J. Application of Turbiscan LAB to study the influence of lignite on the static stability of PCLWS. Fuel 2018, 214, 446-456. [CrossRef]

(C) 2020 by the authors. Licensee MDPI, Basel, Switzerland. This article is an open access article distributed under the terms and conditions of the Creative Commons Attribution (CC BY) license (http://creativecommons.org/licenses/by/4.0/). 